\title{
"Principle, Interest and Patriotism All Combine": \\ The Fight over Iowa's Capital City
}

\author{
SILVANA R. SIDDALI
}

AS IOWA made the transition from territory to state in the $1840 \mathrm{~s}$ and 1850s, its settlers and leaders battled over the location of the state capital. This struggle-in Iowa as well as in several other territories - erupted as part of a larger pattern of battles over democratic representation in the new states carved out of the Old Northwest Territory and the trans-Mississippi West. ${ }^{1}$ Such battles were fought not only on a political and ideological terrain, but also on the physical landscape. They were critical for the future of frontier towns. Winners could expect to enjoy the prosperity that capital status would surely bring. On the other hand, many of the towns platted by speculators vanished or were abandoned after a few years, so the battle over capital city status could become a fight for survival. ${ }^{2}$

I am grateful to my colleagues at Saint Louis University, who read drafts of this article in the History Faculty Research Seminar, to Chandra Miller Manning at Georgetown University, and to research assistant Cynthia Stachecki. I would also like to thank the State Historical Society of Iowa for the research grant that enabled me to complete the research for this article.

1. Hereafter, I will use the term Midwest (even though it was not used at the time) to refer to the region that includes the states carved out of the original Northwest Territory (Ohio, Michigan, Indiana, Illinois, and Wisconsin), plus Iowa, Minnesota, Kansas, Nebraska, and Missouri.

2. Fights over geographic objectives were of such crucial importance that they sometimes escalated into violence, as they did in the midwestern "county seat wars" or in armed conflicts over state boundaries. Historian James Schellenberg argues that Iowa had one of the most violent and contentious histories in the annals of American county seat wars. James A. Schellenberg, "County Seat THE ANNALS OF IOWA 64 (Spring 2005). (C) The State Historical Society of Iowa, 2005. 
Antebellum settlers in the region considered their state capitals to be visible symbols of democracy and equal representation. Most of the newly formed territories and states eventually moved their capitals in order to accommodate the demands of a rapidly expanding population. But these "removals," as they were called, never came easily or quietly. Because state capitals also represented economic, social, and cultural opportunity, any promising town that fit the basic criteria fought hard for the distinction of becoming the capital of the new state. These fights broke out in many arenas-the territorial and state legislatures, state constitutional conventions, the columns of partisan newspapers, and private parlors and hotel rooms. An examination of these conflicts reveals a participatory democracy that consisted of an innovative mix of raw opportunism, confidence, experimentation, and a highly local sectionalism - alongside a roughand-ready justice. Local boosters, settlers, and investors used whatever tools came to hand, including personal connections and friendships, as well as political alliances. Their methods may have been opportunistic, but they usually resulted in a democratic decision that moved the capital city closer to the center of their state as the population expanded. Democracy was worked out-and reflected on the land.

Even though these debates did not revolve around national party platforms, politicians and parties did play a role, and they provided the stage on which the drama was played out. The combatants had no compunction about hurling political insults at one another. In fact, their rhetoric often made use of party slogans. But their efforts to hold on to (or to acquire) the capital in their own cities transcended or ignored party platforms. At

Wars: A Preliminary Analysis," Journal of Conflict Resolution 14 (1970), 345-52. See also Daniel J. Boorstin, The Americans: The National Experience (New York, 1965), 164-66. For state boundary conflict between Iowa and Missouri, see Carroll J. Kraus, "A Study in Border Confrontation: The Iowa-Missouri Boundary Dispute," Annals of Iowa 40 (1969), 81-107. On the vital consequences of selecting the location of capital cities, see Glenn R. Carroll and John W. Meyer, "Capital Cities in the American Urban System: The Impact of State Expansion," American Journal of Sociology 88 (1982), 565-78. For example, two of Alabama's early state capitals became "ghost towns" in the early nineteenth century. Sam Earle Hobbs, "History of Early Cahaba, Alabama's First Capital," Alabama Historical Quarterly 31 (1969), 155-81; and Nan Fairley, "The Lost Capitals: St. Stephens and Cahawba," Alabama Heritage 48 (1998), 18-31. 
the same time, partisan culture did sometimes influence the contestants' attitudes toward the debates over geographic advantages. In Iowa, for example, Whigs often advocated caution, and argued for a careful development of internal improvements, while Democrats pushed for quick settlement. ${ }^{3}$

In the Midwest, debates over the location of capitals, internal improvements, and other geographic advantages rested on two unshakeable assumptions. First, political equality had to be represented on the landscape in matters such as the fair placement of boundaries between states and between counties; and in the apportionment of internal improvements and public institutions; but most of all, in the central location of many county seats and nearly all state capitals, especially in the newer states. The notion of centrality was so vital to settlers that it could preempt all other arguments - even highly self-interested ones. Centrality was justice. The location of a capital city in the middle of a state or territory promoted fair access to the seat of government, expedited travel to the capital for delegates from all parts of the territory or state, and made courts accessible to most residents. ${ }^{4}$

The second widespread assumption was that most of these decisions about the central location of capital cities had to be written into the new states' founding documents. Even in the strongly Democratic midwestern settlements, such decisions were rarely left to state legislatures or to popular referendum. Instead, they were secured in the state constitutions, partly to prevent future fights over capital cities, and partly to enshrine the idea of central access in the document that framed the state's character and destiny. The distinctive nature of capital city fights in states such as Iowa force us to re-examine the relationship between self-government, constitutionalism, and historical geography as these forces played out in the lives of white Americans forging new democracies on the western frontier.

3. Boorstin, The Americans, 95. See also Richard C. Wade, The Urban Frontier: The Rise of Western Cities, 1790-1830 (Urbana, IL, 1996), esp. chap. 5.

4. Rosemarie Zagarri, "Representation and the Removal of State Capitals, 1776-1812," Journal of American History 74 (1988), 1239-56, argues that the choice of state capitals in the colonial northeast provided a physical representation that was not yet in place in colonial governments. See also David Ralph Meyer, "A Dynamic Model of the Integration of Frontier Urban Places into the United States System of Cities," Economic Geography 56 (1980), 120-40. 
THE STORY of Iowa's first territorial capital provides an early example of democratic experimentation and questionable bargains. From the moment the Iowa Territory was opened to white settlers, tiny villages began fighting for ascendancy and advantages. After the Black Hawk War, the Sauk and Meskwaki were forced to give up their tribal lands along the Iowa River under the provisions of the Purchase Treaty of 1832. Although that treaty did not specifically open the surrendered lands for settlement, the removal of the Indians proved to be the impetus for thousands of emigrants to cross the Mississippi. By the early 1830 s, settlers had already incorporated towns such as Dubuque, Davenport, Bloomington (now Muscatine), Burlington, Fort Madison, and Keokuk along the Mississippi River. Settlement in the Iowa Territory followed the typical pattern of the American "urban frontier," which began with village settlements (rather than with isolated farms) along riverbanks or in areas of raw material production. These towns also provided basic services to settlers, including dry goods stores, blacksmiths, carpenters, and saw and grain mills. These newly settled villages became the locus of intense speculation as farsighted entrepreneurs scrambled to gain a foothold in towns that promised success. ${ }^{5}$

In 1834 Congress consigned the former Sauk and Meskwaki lands in what is today Iowa and Wisconsin to the Michigan Territory in order to establish temporary legal jurisdiction over the new settlements. The arrangement was never intended to be permanent. Within two years, when Michigan was ready to enter the Union, the lands west of Lake Michigan were separated into a new territory, called Wisconsin Territory. To organize the territory, Congress chose the tiny village of Belmont as the temporary capital. Territorial legislators soon condemned it as inadequate. Burlington then served as the capital of the Iowa District from 1838 to 1841 .

In the meantime, the territory's population grew considerably. By the mid-1830s, more than ten thousand settlers had arrived. They soon demanded government, roads, and access to markets. According to many midwestern settlers, there was no point in establishing roads and planning transportation networks until

5. For a discussion of the "urban frontier," see Wade, Urban Frontier. 
the site of the territorial capital had been determined, because most agreed that the main roads had to lead to the capital. As a result, the question arose whether Burlington would remain the capital or if some other city would gain the honor.

Immediately, the issue of the capital city's location became imbued with frontier-style politicking - a mix of personal enmities and a shrewd assessment of future territorial growth. Territorial Governor Robert Lucas (formerly governor of Ohio) personally toured all of the river towns to determine possible candidates for the location of the state capital. Because he was plagued by a personal antagonism with the territorial secretary, William Conway, a Davenport booster, and also because he had been deeply impressed with other towns, Lucas ignored Davenport's claims. In addition, he believed that choosing one of the existing cities would create jealousies; and in any case, none-including Burlington, which Lucas himself had selected as the territorial capital in 1838-were central to the entire territory, which was rapidly expanding westward. ${ }^{6}$

A bitter rivalry ensued in the territorial assembly over the choice of a new capital. Mount Pleasant nearly won, but the fights between towns led to a resolution to call for a completely new site. Therefore, in 1839 the territorial assembly provided for three commissioners, one from each "judicial district" and chosen by joint ballot to ensure a fair decision. The commissioners - Chauncey Swan, a prominent citizen and staunch Democrat from Dubuque; John Ronalds of Louisa County; and Robert Ralston of Des Moines County (in extreme southeast Iowa)were to choose a fresh location for the capital in Johnson County, and to lay out the town in lots, streets, squares, and alleys.? Geographic fairness trumped politics or other considerations, although all three men were persons of some standing in their communities. The commissioners chose a site in Johnson County, near the center of the settled portion of the Iowa Territory, though rather distant from the center of population. The site was about 60 miles west of the Mississippi River and between 70 and 90

6. Joseph Frazier Wall, Iowa: A Bicentennial History (New York, 1978), 28-29.

7. Leland Sage, A History of Iowa (Ames, 1974), 50-52, 57, 62; Benjamin F. Shambaugh, Iowa City: A Contribution to the Early History of Iowa (Iowa City, 1893), 18. 


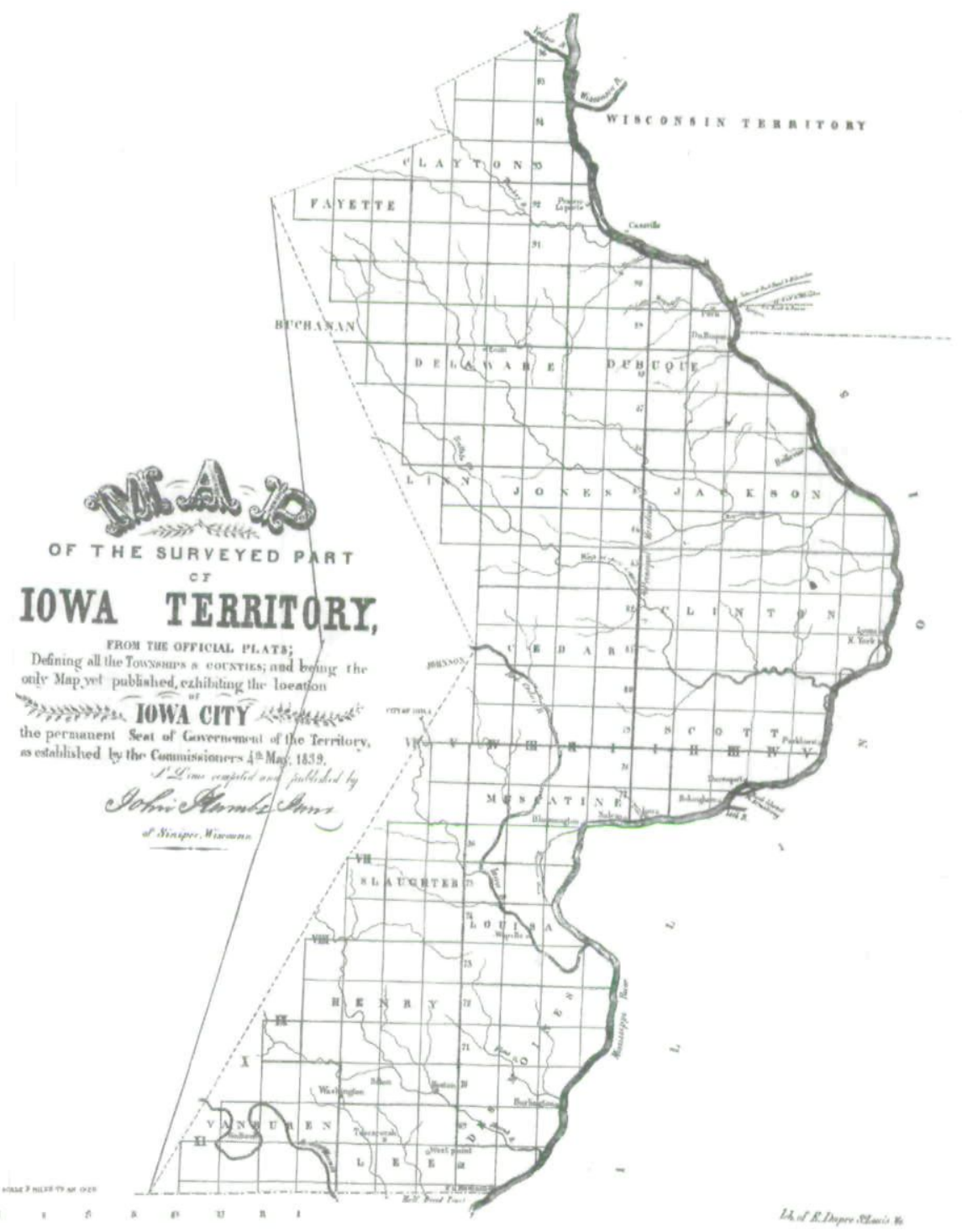


miles from most other settlements. The selection demonstrated optimism about the future growth of the territory, as well as a firm commitment to the idea that territorial capitals must be located as closely as possible to the center of a growing population.

The dispute over the selection of Iowa's capital city followed a familiar pattern. Most territorial or new state capitals in the United States were chosen after bitter fights, although the worst violence was generally reserved for vituperative newspaper editorial rhetoric. Because of the potential for conflict, territorial assemblies (usually directed by the governor) often created new capitals in an unsettled area rather than destabilizing a fragile frontier society by awarding the prize to an existing town. Sometimes the choice of a site for a capital city was the result of careful negotiation between competing districts. Such compromises over capital cities had a long history in America, including, of course, in the creation of the District of Columbia. State capitals specifically created, rather than awarded to existing cities, include Columbus (Ohio), Vandalia (Illinois), Indianapolis (Indiana), Raleigh (North Carolina), and Columbia (South Carolina). ${ }^{8}$

In Iowa, despite incipient rivalries for the honor of being chosen as the territorial capital, most parties agreed that the Johnson County site fit the criteria for a capital city: it was centrally located, boasted plenty of wood and "inexhaustible" stone building materials, and was deemed to be both healthy and beautiful. In an uncharacteristically cooperative moment, the fiercely Whig Burlington Daily Hawk-Eye reprinted verbatim an editorial from its hated archrival, the Democratic Territorial Gazette, describing the site. The town was to be built between two high and level plains on the northeast bank of the beautiful Iowa River, which flowed through "thick groves of stately [oak] trees" and was deep enough for keel- or flat-bottomed boats. More importantly, the future capital of Iowa would always be

8. I am indebted to research assistant Cynthia Stachecki of Saint Louis University for this information. New towns and villages in British colonies such as Australia, New Zealand, or Canada were usually settled in reference to London. New American states, by contrast, did not consider the importance of the national capital (Washington, DC) or regional centers (such as, for example, St. Louis) when situating their own capitals. For comparison with European capital cities, see David R. Ringrose, "Capital Cities, Urbanization, and Modernization in Early Modern Europe," Journal of Urban History 34 (1998), 155-83. 
"supplied with pure spring water" from the "fountain springs of the Iowa and Cedar Rivers." Great stands of timber grew nearby, and although the area was sparsely settled, a sawmill had already been established about three miles distant on Rapid Creek. The writer praised the site's "surpassing beauty"; the "most fanciful imagination," he wrote, "can hardly picture to itself so enchanting a spot, situated in the midst of all that wild natural scenery." This sort of assessment of midwestern settlements was fairly typical. After lyrical descriptions of the riverbanks, observers casually commented that they could be looted for building materials. Such descriptions presented a combination of bold pragmatism, unregretful nostalgia, and an appreciation for nature as a generous benefactor, not as a wild frontier.'

The General Assembly determined the name of the capital by law in 1839. European observers sometimes mocked the American tendency to burden every fledgling settlement with the grandiose name of city, but such a designation marked a confident hope for a modern, "civilized" future and an eagerness to leave the frontier behind and embrace the benefits of civilization. ${ }^{10}$ There were few roads in the Iowa Territory in 1839 , but boosters were confident that transportation would (and should) soon come to Iowa City. The lack of roads did not prevent American and European emigrants from pouring into the territory by the thousands, now that the Indians had been forced or bought out. Indeed, speculators quickly descended on the capital city site. Surveyors began platting the town in July 1839 ; and by 1842 , Iowa City was a lively, bustling scene, boasting 700 regular inhabitants in addition to the territorial legislators, lawyers, judges, and travelers connected with political and court business. Settlers in the little town had already established several grocery, drug, and dry goods stores, at least one newspaper (the Capital Reporter), a hotel, one church, and a primary school. ${ }^{11}$

9. Territorial Gazette (Burlington), quoted in the Burlington Daily Hawk-Eye, 6/6/1839; Shambaugh, Iowa City, 35-36.

10. David Hamer, New Towns in the New World: Images and Perceptions of the Nineteenth-Century Urban Frontier (New York, 1990), 115.

11. Shambaugh, Iowa City, 37. 
AS EARLY AS THE MID-1840s, residents of the rapidly growing settlements in the northern and western areas of the Iowa Territory were already beginning to insist that the capital be moved westward, because they did not have ready access to the territorial assembly and courts. Historian Daniel Boorstin believed that the mobile nature of state capitals and county seats proved that "Americans viewed their governments functionally." That is, governments were put in place to serve citizens, and had to move to suit the people's changing needs. ${ }^{12}$ But disputes over the location of capital cities may also be evidence of fierce local loyalties, and a sign that government should be eminently responsive to the people; that is, they reveal a close identification between the ideals of democratic self-government and more pragmatic concerns, such as the economic success of a new city.

In any event, the demands for the removal of the capital incited sharp rivalries among the centrally located county seats that contended for the honor of becoming the capital. Local businessmen, newspaper editors, and politicians used all of the tools, friends, and weapons at their disposal to situate the seat of government where it would do them the most good. But the prospect of the "capital removal" rivalry rendered Iowa City residents and boosters uneasy. Who would have the final say in the choice of a new capital? The Iowa Standard spoke for many of its Iowa City readers when it worried that "the people on the Desmoines river would claim it-Burlington would expect itthe West would insist upon its geographical, central positionwhile the North would vehemently oppose its removal to any point farther away from it. Our people in all parts of the Territory would be involved in jealousies and bickerings, which would never be settled..$^{13}$

Which is precisely what happened. By 1844 , more than 75,000 people lived in Iowa, and the Democrats thought that the territory was ready to apply for statehood. Whigs dragged their feet on the issue because they were in a minority, and they hoped to build political strength before establishing a state government. Whig newspapers and politicians advocated caution, claiming

12. Boorstin, The Americans, 94-95.

13. Iowa Standard (Iowa City), 7/30/1845. 
that the territory was not yet stable or solvent enough to support its own government. But the more numerous Democrats won the call for a state constitutional convention, to be held in Iowa City later that year. In that body Democrats outnumbered Whigs more than two to one, so the resulting document was a strongly egalitarian, anti-bank, Democratic instrument. But it did leave the capital at Iowa City for 20 more years. Unfortunately, despite the Democrats' majority and their concessions to Iowa City, the bid for statehood failed, though the reasons had little to do with local politics. Hoping to rush the process through Congress, and believing that a popular referendum was unnecessary, the convention delegates had neglected to submit the constitution for a popular vote to the residents of Iowa. When the U.S. Congress severely curtailed Iowa's boundaries as a condition for admission to the Union, the territorial residents voted down the constitution-which effectively postponed statehood. $^{14}$

Congress had trimmed the proposed state boundaries in order to increase the number of free states that could be created from the Iowa and Wisconsin territories, so the struggle for Iowa's statehood played a role in the national sectional conflict. But inside the Iowa Territory itself there was another sectional battle-one that had nothing to do with the national debate over the extension of slavery. Indeed, the rivalries over geographic objectives such as capital cities reveal that American antebellum sectionalism often extended beyond national political contests, although the local fights retained all the acrimony of the national ones. In the debates over the location of state capitals, moreover, one finds frequent use of the word sectionalism -not just in Iowa, but in many other midwestern states as well. ${ }^{15}$

14. Territorial Gazette (Burlington), 12/12/1844, quoting a Burlington Hawk-Eye editorial. The rules for territorial admission to statehood did not stipulate that the state constitution had to be ratified in a popular referendum, although most new states did submit their constitutions to the people for a general vote.

15. See also, for example, D. Duff McKee, "'The People vs. Caleb Lyon and Others': The Capital Relocation Case Revisited," Idaho Yesterdays 36 (Summer 1992), 2-18; Stephanie D. Moussalli, "Choosing Capitals in Antebellum Southern Frontier Constitutions," Southwestern Historical Quarterly 101 (1997), 58-75; James B. Potts, "The Nebraska Capital Controversy, 1854-59," Great Plains Quarterly 8 (1988), 172-82; Paul E. Stroble, "The Vandalia Statehouse and the 
The word sectional in those contexts was used to describe enmities between eastern and western or northern and southern settlements within a territory or state and rarely had anything to do with national issues, such as the debates over the expansion of slavery. In contrast to the national sectional conflict, the territorial and state debates were purely concerned with geography, not ideology. For example, Iowa Whig William Penn Clarke was sure that statehood had been sacrificed to local "sectional" jealousies and conspiracies against northern Iowa. The southern part of the territory, he asserted, had "manifested an increasing hostility" to the "North" (meaning northern Iowa). He was convinced that the "South" wanted the shorter boundaries for no other reason than to steal the capital away from Iowa City. That is, because everyone agreed that the capital had to be situated near the center of the territory, those shorter boundaries would force Iowans to move their capital. Those who voted for the ratification of the constitution, then, would "do so with the ... moral certainty that the removal of the seat of government from this point, will be one of the first consequences of its adoption. ${ }^{\prime 16}$ Clarke was a strong partisan and a good Whig, but nowhere in his letter did he refer to slavery or to the national sectional conflict.

Such quarrels, which might be described as a kind of "local sectionalism," echoed many of the characteristics of national sectionalism: attempts at negotiation and compromise, as well as threats and sometimes even outbreaks of violence. However, regional issues were easier to settle. The fierce local loyalties, often expressed in the mid-nineteenth century by the word jealousy, were usually resolved in deals cut in the lower house of the General Assembly. Negotiation, conciliation, and compromise, were, after all, the hallmarks of the American democratic process. No town was willing to concede advantages without gaining something in return, such as the fair distribution of roads or railroads, or public institutions such as universities or

Relocation to Springfield," Illinois Heritage 2 (Spring-Summer, 2000), 12-19; Neil B. Thompson, "A Half Century of Capital Conflict: How St. Paul Kept the Seat of Government," Minnesota History 43 (1973), 238-54.

16. Benjamin F. Shambaugh, Fragment of the Debates of the Iowa Constitutional Conventions of 1844 and 1846 (Iowa City, 1900), 286, 361-64. 
prisons. For example, the State University of Iowa had been established at Iowa City in 1847, and there was some discussion in the various constitutional conventions about relocating the university as well as the capital. Iowa City was determined to hold on to the university at all costs, however, especially as the new western counties became more vocal about relocating the capital.

In the middle to late 1840 s, Iowa City residents expressed mounting anxiety about the possibility that the capital would be moved westward. Newspapers hurled accusations of fraud, bribery, even conspiracies, and did their best to drag party politics into the debate. In the intense rivalry between the former and present capitals, Burlington and Iowa City, for example, the Whig editor of the Burlington Hawk-Eye regretted that the people of Johnson County proposed to vote for the constitution "simply because that instrument fixes the seat of government at Iowa City" for 20 more years. The Iowa Capital Reporter, a Democratic paper published in Iowa City, responded, calling the Hawk-Eye editor a "knave and fool" and his editorial nothing more than the usual Whiggish "secret midnight incendiary lies." No one, the Reporter claimed, would ever find proof that any "sectional consideration" had ever been "held out to the people of Johnson county or the North" to vote for the constitution in order to secure possession of the capital. Indeed, in a vituperative conclusion that hinted strongly at the importance of geographic prizes in territorial debates, the editor claimed that these Whig "political jugglers" had used the thorny issues of the territorial boundaries and the capital to "operate upon the prejudices of the South and to [aggravate] jealousy against" Iowa City. ${ }^{17}$

But removal was becoming inevitable. Beginning in the early 1850 s, western farmers sent petitions to the General Assembly to relocate the capital, and their representatives responded by proposing bills for removal. Petitions presented at every legislative session revealed that many Iowans were now convinced that Iowa City was too far from the new geographic and population center of the state. As the most vocal boosters with the widest audience, newspaper editors took the lead in fighting for their hometowns.

17. Iowa Capital Reporter, $7 / 14 / 1847$. 
The contestants hotly denied charges that the capital issue was a partisan question, and they portrayed themselves as virtuously disinterested. Nonetheless, the battles over geographic advantages such as internal improvements, boundaries, and capitals had to be fought out in the political arena, and the contestants had to use political party organizations, resources, and rhetoric to achieve their ends. Politicians desiring election knew that they had to pay attention to local opinion on the capital question. For example, when Lysander Babbitt announced his candidacy for the General Assembly in 1850, he informed the voters of central Iowa that he considered it his duty to "use all honorable means to procure" the state capital. ${ }^{18}$

IN THEIR VERBAL ASSAULTS on one another, both sides used familiar political rhetoric, sometimes deliberately manipulating their opponents' shibboleths and catch phrases to entice support. For example, Iowa City's Democratic Capitol Reporter was incensed that the Whig Burlington Hawk-Eye was using Democratic Party slogans to manipulate the emotions of Iowa voters. The Hawk-Eye's claim, for example, that leaving the capital in Iowa City would be a "monopoly" (presumably because the city had retained the capital for so long) was clearly, in the Capitol Reporter's view, "designed to rouse Democratic anger." The Whiggish plot, the editor insisted, had now been "laid bare." Although in this case the Hawk-Eye was cleverly making use of the opposing party's political slogans, most Iowa politicians and boosters remained deeply committed to their own party values in their arguments.

Political organizations and loyalties played a significant role, but they were more fluid in the antebellum Midwest than in the more established regions. For example, support for internal improvements remained an important plank of the Whig national political platform. But midwesterners of all political stripes understood the importance of building transportation networks aimed at improving and extending markets and communication both within the state and with the eastern states. Still, the most

18. Iowa Star, 8/1/1850.

19. Iowa Capital Reporter, 7/30/1847, reprinting a Burlington Hawk-Eye editorial. 
explicit arguments that capital site location would bring internal improvements appeared in Whig papers, while Democratic papers rather stressed the rivalry for these improvements. ${ }^{20}$

Because of their adherence to the importance of the "centrality" of public institutions and roads as the best guarantor of democratic justice, both Whig and Democratic papers agreed that the precise location of internal improvements ought to be determined before the state became fully settled, and that the capital city must become the radiating center for future transportation networks. The Whig Oskaloosa Herald stressed that the state capital should be removed as soon as possible because its present location was inconvenient to "north, south and west, while the unsurpassed increase of population in the south and west, render it anything but equitable in its location to them." "It is desirable to have the question definitely settled as soon as practicable" because the location of the permanent site would determine the "locating of Railroads, Plank roads \&c." ${ }^{21}$

This sentiment was so pervasive that both Democratic and Whig newspaper editorials expressed it with equal vehemence, even though traditional Democrats-those outside of the western territories-usually opposed massive internal improvement projects, deeming them unconstitutional. Western Democrats (sometimes known as the "Young America" faction of the Democratic Party) supported river, harbor, and road improvements, however. For example, Des Moines's Democratic paper, the Iowa Star, declared that the sooner the capital was located where it would be permanent, "so that the works of internal improvements, . . . can be made in reference to it," the better it would be for the whole state. ${ }^{22}$ The debates for and against internal improvements can be difficult to reconcile with national or regional party platforms, but it remains clear that the commitment to

20. For the values and commitments of antebellum political parties, see Daniel Walker Howe, The Political Culture of the American Whigs (Chicago, 1979); and Jean Harvey Baker, Affairs of Party: The Political Culture of Northern Democrats in the Mid-Nineteenth Century (Ithaca, NY, 1983). For the political culture of early Iowa, see Robert Cook, "The Political Culture of Antebellum Iowa: An Overview," Annals of Iowa 52 (1993), 225-50.

21. Oskaloosa Herald, $8 / 27 / 1852$.

22. Iowa Star, $11 / 7 / 1850$. 
centrality and geographic justice often outranked national party commitments. $^{2}$

Sometimes party culture remained powerfully influential. Whigs, for example, insisted on developing internal improvements before rushing forward with settlement. Iowa Whigs also wanted to retain territorial status longer in order to build a stronger political base. Whig cautiousness had led some Whigs in Iowa City to oppose the extremely Democratic, egalitarian, anti-bank constitutions of 1844 and 1846, even though both constitutions guaranteed that their city would remain the capital for 20 more years. The Iowa Standard, an Iowa City Whig paper, conceded that retaining the capital was vital to the well-being of Iowa City, and that those who owned property or businesses there might "without great impropriety" vote differently from those who were "not so deeply interested." But there was no need to fear, because Iowa City had "possession of the Capitoland possession is said to be 'nine points of the law.'" The removal question was only being agitated by a few "noisy partisans, who hope to ride into office on the hobby." Probably the wisest course, until all this was settled, was for Iowa to remain a territory for a few more years. There was no reason to sacrifice principle to interest. In any case, "principle, interest, and patri-

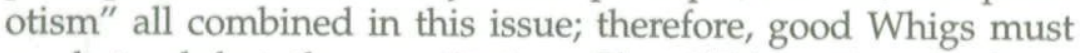
work to defeat the constitution. That Whig writer (and, no doubt, many Democrats) defined patriotism rather narrowlyas loyalty to a single town. ${ }^{24}$

Even Des Moines Whigs expressed caution about removing the capital. The Whig Des Moines Courier (true to its party's nature) advocated prudence, even though it supported removal of the capital, and even though removal would clearly redound to its benefit. According to the paper, everyone agreed that the capital should be removed, but it was not clear "whether now is the right time." Still, although for the next two years the Courier strenuously denied feeling any "interest" in the question, the pa-

23. Yonatan Eyal, "'Rift in the Democracy': Young America, Rivers and Harbor Improvements, and the Old Northwest" (paper presented at the Edgefield, South Carolina, meeting of the British-American Nineteenth Century Historians, March 2005).

24. Iowa Standard, 7/30/1845. 
per continued to tout the advantages of Des Moines as the next state capital. Similarly, the Whig Fairfield Weekly Ledger declared that "the capital should not be moved for at least ten years." Furthermore, the editor declared, with characteristic Whiggish faith in internal improvements, that the "eastern portion of the State will always be the most densely populated, and but a few years will elapse until we have facilities for travel sufficient to render it immaterial where, indeed, our capital is. ${ }^{\prime 25}$

But Democratic papers had no patience with Whiggish prudence. Des Moines's Democratic paper, the Iowa Star, explained that although caution might once have been reasonable, the time had now come to take action. The Star reminded its readers that four years earlier a majority of the members of the General Assembly had not thought it premature to pass a law removing the capital. (The lower house had passed the bill but the senate had tabled it.) By 1850, the central and western portions of the state had become settled to such an extent that longer delay would be "rank injustice . . . and an injury to the people generally in the State." Explaining why "soon" was the most auspicious time, the editor declared that good building sites could be "much more easily and conveniently obtained" before the country had become "densely populated and covered over with valuable improvements." In and around Fort Des Moines, for example, there were "two or three beautiful sites which would now be procured-would be donated to the State for that object, that could not after two or three years more be obtained, as they would in all probability be laid out into lots, and covered over with houses and other improvements. ${ }^{\prime 26}$

Generally, though, the capital city issue transcended party politics. Despite their differences, in Iowa City both Democrats and Whigs fought to keep the capital, and in Des Moines both parties struggled to obtain it. Democrats and Whigs shared a booster ethos. ${ }^{27}$ Both employed the language of boosterism in

25. Des Moines Courier, 11/11/1850, 12/9/1852; Fairfield Weekly Ledger, 12/23/ 1852.

26. Iowa Star, $11 / 7 / 1850,11 / 21 / 1850$. See also ibid., 12/12/1852.

27. For an explication of the booster ethos in one Iowa town during this period, see Timothy R. Mahoney, "The Rise and Fall of the Booster Ethos in Dubuque, 1850-1861," Annals of Iowa 61 (2002), 371-419. 
their fight for the capital city. Both also were capable of assessing the value of natural resources in their own neighborhoods, and both sides displayed a ready willingness to make use of them in their drive toward advancement and progress.

Mid-nineteenth-century boosters (newspaper editors, politicians, speculators, and private investors) expressed a lofty confidence in the benefits of modern civilization. They might have appreciated the magnificence of natural landscapes, but they quickly developed a sharp-eyed, realistic view of the importance of hinterlands for building and maintaining prosperous cities. Their rhetoric may have waxed poetic, but their appreciation of natural beauty in no way prevented them from advocating the rapid and thorough exploitation of those natural resources, even to the destruction of a landscape they admired. Nature had to yield - and very quickly, too- to civilization and progress. The Iowa Star, for example, reaffirmed all of the advantages of Des Moines's resources, hinterlands, trade, river navigation, and building materials, and declared that the great tide of immigration, like a "mighty wave, moving westward" was now "transforming our beautiful Prairies, as if by magic, into highly cultivated farms."${ }^{\prime 28}$

IN THE CONTEST for the location of the capital city, private citizens - especially businessmen and speculators-as well as newspaper editors, politicians, and candidates for political office, played an important role. Whenever the question of removing the capital arose in the General Assembly, investors in the contending towns immediately made offers of town lots, funding and materials for the construction of public buildings, or rent-free accommodations. In 1839, for example, Walter Butler, a prominent Iowa City businessman, had donated a building for the first state capitol while the beautiful new stone capitol was being constructed. Similarly, in the early 1850s, when the town of Des Moines had become a viable contestant for the capital, its boosters would vie with one another to offer valuable town lots for the construction of the state capitol there. In the midwestern capital city contests, such offers were, in effect, shrewd invest-

28. Iowa Star, 1/13/1853. See also ibid., 12/31/52. 
ments by entrepreneurs who had already bought property in the hinterlands surrounding these towns.

For the hard-strapped midwestern state governments, such donations were a crucial element in determining the site for a capital city. In early 1852, for example, a capital relocation bill passed by Iowa's General Assembly provided that commissioners empowered to examine contending towns must "take into the account ... the amount of donations proposed to be given to the State for the erection of public Buildings. ${ }^{129}$ Reliance on private donations could, however, lead to fraudulent dealings and influence peddling. Robert Gower, a delegate to the 1857 constitutional convention, bitterly complained that corruption and bribery had been used to force the removal from Iowa City. He quoted from a letter written by a state representative who had received gifts and entertainment and who declared his intention to "remove to Fort Des Moines" after purchasing town lots there at a low price, because property there would become "very valuable if the [removal] act passed and became a law." According to Gower, the means used to induce legislators to vote for the act were "money, town lots, and oyster suppers. ${ }^{130}$

On the American frontier, the economic value of town lots and the surrounding farmlands depended more on the contributions of private speculators than it did in similar settlements in other developing societies or in Europe. Urban historians have stressed the importance of hinterlands for the growth and vitality of European cities. The potential economic growth of European cities was easier to gauge than that of nineteenthcentury American or Canadian frontier towns, however, because the surrounding areas of European cities were already populated and their farmlands more fully developed. American speculators and settlers certainly understood that without rich surrounding farmlands a city could not succeed. But perhaps more importantly, in the American Midwest, the situation was more uncertain because hinterlands could not be improved without the labor and investment of "the right kind" of settlers,

29. Des Moines Courier, $12 / 9 / 1852,1 / 6 / 1853$.

30. The Debates of the Constitutional Convention of the State of Iowa, Assembled at Iowa City, Monday, January 19, 1857, 2 vols. (Davenport, 1857), 2:922-25. Robert Gower was the delegate from Cedar County. 
those who would be attracted by the goods and services available in developing towns. ${ }^{31}$

This was one of the most vital elements in the fight for a capital city; a town's status and prestige and its centrality in future transportation networks would attract teachers, lawyers, and other professionals, not to mention the kinds of emigrants who would know how to cultivate the soil. The Iowa Star, in boasting about surplus grain crops, explained that the surplus was a result of Fort Des Moines's success in "attracting the best people." The Whig Des Moines Courier also commented that although its city was "not exactly in the centre of the State," it was close enough to roads and waterways to make the city easily accessible to emigrants - a consideration the paper considered "of the utmost importance." ${ }^{\text {"32 }}$

Moreover, Des Moines had an abundant supply of water, which was "indispensable to the growth and security of cities." Whig papers, especially, were keenly aware of the necessity of exploiting the natural resources contained in the hinterlands surrounding new towns. The Whig Oskaloosa Herald explicitly stated that the prosperity of new towns "depended altogether upon the natural resources of their respective counties." According to the Herald, Oskaloosa had always been "backed up by the immense riches of Mahaska County" and had now "moved into wealth and distinction." In comparison, Fort Des Moines was nothing but a "moon-struck village" that did not deserve the honor of being chosen as the state capital. ${ }^{33}$

NINETEENTH-CENTURY AMERICANS, especially those who understood farming or who had some experience in the western territories, were good judges of the health, fertility, and prospective prosperity of the land. But they sometimes made

31. David R. Ringrose, "Capital Cities, Urbanization, and Modernization in Early Modern Europe," Journal of Urban History 34 (1998), 155-83. For the American context, see also Timothy R. Mahoney, River Towns in the Great West: The Structure of Provincial Urbanization in the American Midwest, 1820-1870 (New York, 1989), esp. chap. 5; and William Cronon, Nature's Metropolis: Chicago and the Great West (New York, 1991), 264-65.

32. Iowa Star, 5/15/1851; Des Moines Courier, 12/9/1852.

33. Oskaloosa Herald, 2/6/1857. 
mistakes, usually born of overconfidence. ${ }^{34}$ Few American "pioneers" feared the overdevelopment of cities or towns, as did their European counterparts or settlers in other developing societies, but they were certainly aware of the dangers of overextension, which in their minds were often linked to corruption and speculation. It was deplorable, according to the Democratic Iowa Star, that every town in Iowa "seems determined to be the metropolis of this rich and beautiful State. But each of them will not succeed in their praiseworthy efforts. ... Those that fail, will do so ... with a heavy debt hanging over them which will be like a mill stone upon the neck of their anticipated prosperity and growth." The Whig editor of the Fairfield Weekly Ledger, cautioning his readers that removal was premature, sincerely hoped that the "good sense of the present legislature will not permit a few hot-headed speculators to lead them off upon any such wild goose chase. ${ }^{\prime \prime 35}$ Iowa settlers, boosters, and politicians may have been wise to be cautious. Hasty investments, speculation in town lots, and overconfidence in the establishment of a county seat or state capital, could ruin the prospects of a new town.

Historian David Hamer has observed that emigrants to other developing societies, such as Australia and New Zealand, feared rapid development of new towns, deeming such growth to be not only dangerous to the local economy and natural resources, but also to the morals of the population, thus impeding the development of cultural and intellectual institutions. By contrast, midwestern town boosters were less concerned about these dangers, but they were still aware of the potential risks involved in overconfidence. It was risky to establish a capital city in an unsettled area. Bringing costly internal improvements to such a site might be perilous if the city failed to thrive or could not attract settlers. ${ }^{36}$

On the other hand, it was equally hazardous to choose a settled city as the capital; the resultant bickering and rivalries might destabilize the fragile political harmony in a new state. Sigourney's Republican paper, Life in the West, was against re-

34. See Conevery Bolton Valencius, The Health of the Country: How American Settlers Understood Themselves and Their Land (New York, 2002).

35. Iowa Star, 5/15/1851; Fairfield Weekly Ledger, 12/23/1852.

36. Hamer, New Towns, 141-42. 
moval, which the editor considered a "gambling speculation." Any state capital ought to be "located as nearly as practicable to the centre of population; but more especially should it be located in the centre of civilization." Comparing Fort Des Moines to "a half-starved robin," the Whig Oskaloosa Herald mocked the town's frantic efforts to achieve capital status. "She has flashed up within the past 18 months, just on the hope that she will be the capitol [sic], and should she fail to secure her hope, nothing can save her from the doom of an over-rated, over-stocked and over-taxed city." Property prices had risen to exorbitant rates, and "why [?] 'Because we expect the Capitol."' According to the Herald, Fort Des Moines was already overstocked with "Dry Goods Merchants, Grocery men etc. ... And ... [was] the county around able to support them? NO!" ${ }^{37}$

Convention delegates, newspaper editors, politicians and other Iowa boosters accepted the risks of rapid urbanization. In spite of the frequent mutual accusations of bribery and corruption, they all wanted their own towns to flourish and grow. A town was a mark of advancing civilization and the spread of modern American democracy. Thus, towns competed not only for county and state capitals, but also for important public institutions, which would draw travelers, emigrants, and investors. Towns that failed to obtain the capital fully expected to be compensated with other institutions, such as insane asylums, prisons, or universities. Consequently, it was important for towns to make a positive impression on visitors, which meant that individual citizens had to develop civic pride in their hometowns. The Sigourney newspaper Life in the West, a proud booster publication, declared that to build an appealing town "requires sound judgment, good taste, an enterprising spirit, and liberal outlays of labor and money." The editor was particularly incensed about the unappealing messes in Sigourney's streets. "When a stranger arrives and sees your streets encumbered with wood-piles, old wagons, buggies, sleds, plows, etc.," as well as "drunk men and other filth and nuisances," it was no wonder that other towns moved ahead in the race for institutional advantages. ${ }^{38}$

37. Life in the West, 11/27/1856; Oskaloosa Herald, 1/23/1857, 2/6/1857.

38. Life in the West, 6/11/1857. See also Hamer, New Towns, chap. 9. 
Such editorials revealed an awareness that a town required the personal commitments of its residents, investment by speculators, and the constant in-migration of travelers and emigrants. On the other hand, there was also a tension between the recognition that growing towns contained dangerous corrupting elements and the notion that the very newness of the place-its recent creation - could lend a lively originality and inventiveness to the enterprise of building a town and its public institutions. For example, doubts about the moral influences of city life arose several times during the 1857 constitutional convention, especially during deliberations about the future location of the state university. Some delegates recognized that parents would not wish their children to be exposed to the moral menace posed by urban life. Harvey J. Skiff, a Republican from Jasper County, observed that many people came to Iowa City "because the State Capitol was located here." Questionable people had been brought to Iowa City "by the inducements held out by state offices, and things of that kind." They were perhaps "not the best class of persons among whom to locate the State University." Hiram D. Gibson, a Democrat from Jefferson County agreed; he believed that Monroe City was a better choice for the state university because of its handsome, more central location, as well as its "beautiful, high, dry, rolling prairie lands." Moreover, the newness of the place bestowed not only natural virtues but also encouraged greater innovation in designing and building public institutions. According to Gibson, if the state university were located in "an entirely new place" such as Monroe City, it could be designed creatively to suit its educational purposes. Further, Gibson explained that an educational institution "ought not to be located in a commercial or manufacturing city, but should be located in a quiet, rural place, where those influences felt in large cities would not be brought to bear upon the students." He demurred that he did not "have a word to say against Iowa City," but it must be clear to all that the city possessed influences to which parents would not care to expose their children. ${ }^{39}$

By the mid-1850s, as the population of the state was expanding rapidly to the west, it was clear to most Iowans that their

39. Debates of the Constitutional Convention, 2:839-40. 


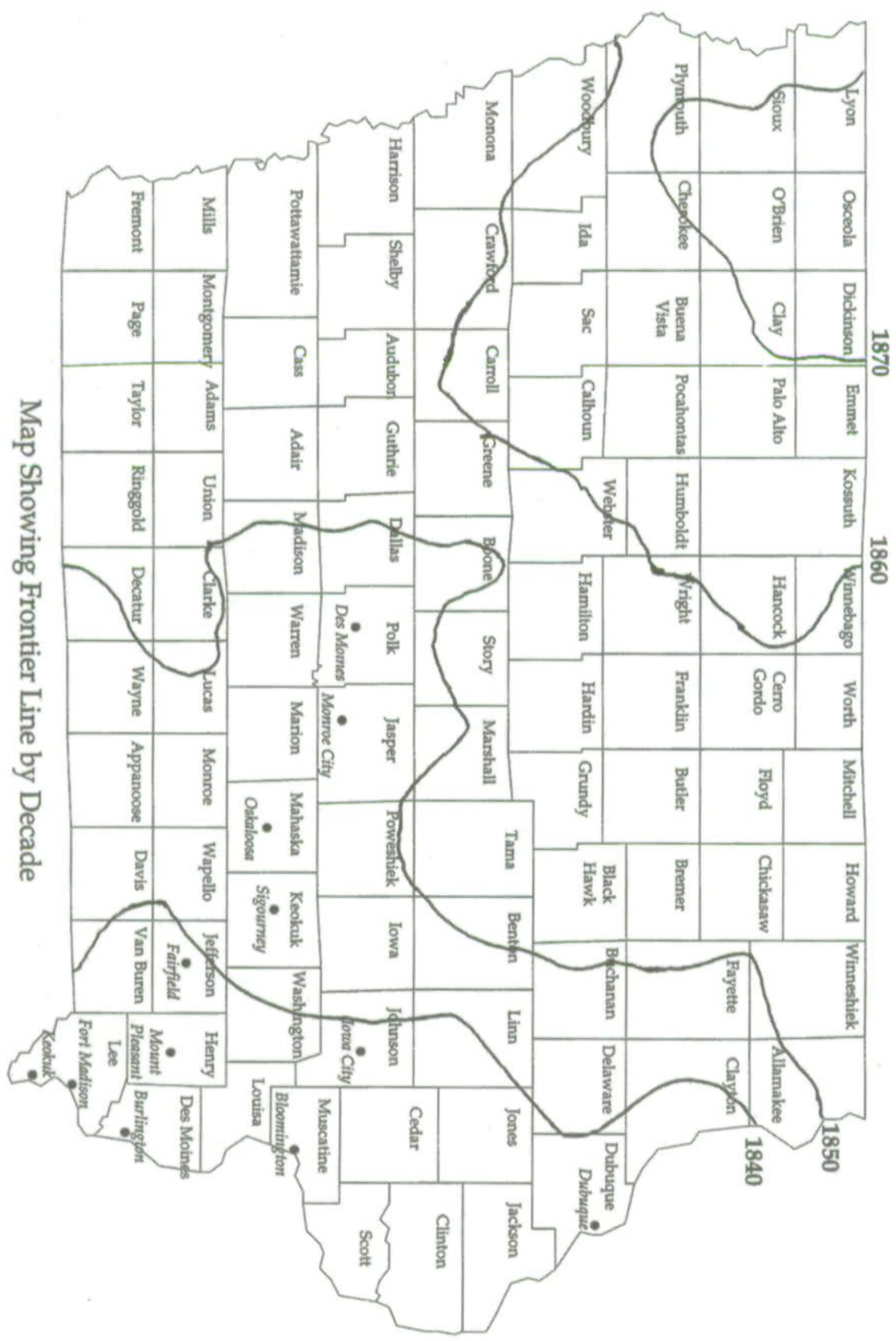


capital would have to be relocated nearer to the geographic center of the state. Polk County, located nearly in the heart of the state at the junction of the Des Moines and Raccoon rivers, and with a population of nearly 10,000 by 1856 , was an excellent choice. Its proximity to the geographic center of the state and its claims of health and the fertility of its hinterlands brought it to the forefront in the capital city debates.

GIVEN THE PROPENSITY FOR LOCALISM, log-rolling, and even fraud affecting such decisions, it is reassuring to contemplate the democratic restraints on rampant opportunism. The first of these was the geographical representation in Iowa's General Assembly. Although county boundaries were often gerrymandered to oblige vocal or influential factions, that was usually done to establish a county seat in a favored town, not to give advantage to one political party over another. Actual numerical representation of political parties remained more or less intact. Indeed, the prospect of shifting county lines or rivalries over the placement of railroads or public institutions, for example, often led to careful negotiations in the General Assembly. That ensured that county courthouses, insane asylums, prisons, and state universities would be apportioned fairly among the contending towns. Second, partisan newspapers played an important role in counterbalancing special or local interests by keeping such debates before the public. Third, no matter how bitterly people fought over capital cities, all agreed that they should be placed as close to the geographic or population center as possible, and that transportation networks should lead to and from the capital. Finally, and perhaps most restrictive to the potential abuses associated with localism, was the surprising practice of "super-legislation," that is, writing into state constitutions provisions that might otherwise be enacted by the legislative assemblies. Thus, all midwestern states except Wisconsin explicitly named their capitals in their constitutions, even though Democrats-who believed that the "capitol of a State, as well as all other public conveniences should be located by the people"held a majority in most midwestern states. ${ }^{40}$ Indeed, before the

40. Ibid., 922-23. 
Civil War, all but eight American state constitutions explicitly named the state capital. ${ }^{41}$

Was it appropriate to settle the capital question in the constitution? Or should it have been left to the state legislature? Or better yet, to the people themselves, in a referendum? Strictly speaking, the purpose of American state constitutions was to frame governments, delineate citizens' rights, and establish courts. ${ }^{42}$ What is less clear is the boundary between such traditional constitutional elements and the kinds of provisions that ought to have been left to legislatures. Although most state constitutions specified the location of capital cities, such provisions carried a strong flavor of antidemocratic meddling and conspiracies against political minorities. Most Democratic delegates to Iowa's constitutional convention in 1857 wanted to leave the decision about locating the capital to the people. But Republicans, who by 1857 outnumbered Democrats both in the constitutional convention (21-15) and in Iowa, were entirely in favor of naming the capital in the constitution because doing so would remove this political "foot-ball" from a legislature that could be corrupted by "sardinian and Chesapeake appliances" (that is, sardine and oyster suppers). The question would thus be settled in a more permanent way, subduing the rivalries that threatened to destabilize the new state. ${ }^{43}$

These considerations figured equally in debates over the location of public institutions such as universities, insane asylums, and prisons. Republican John Edwards of Lucas County, for example, thought that the state university should have been constitutionally located at Monroe City in the first place. "It is proposed to let this matter be submitted to the people. If that is done there will be a half a dozen contestants for each of these institutions." He vowed that he would "never consent to have

41. The eight states were Georgia, Maine, North Carolina, Wisconsin, Massachusetts, New Hampshire, New Jersey, and Pennsylvania. Georgia, Maine, and North Carolina named their capitals in their postbellum constitutions.

42. Laura Scalia, America's Jeffersonian Experiment: Remaking State Constitutions 1820-1850 (De Kalb, IL, 1999).

43. Debates of the Constitutional Convention, 2:925, 928-29, 839; Life in the West, $11 / 27 / 1856$. For the political affiliations of delegates to the 1857 convention, see Robert R. Dykstra, Bright Radical Star: Black Freedom and White Supremacy on the Hawkeye Frontier (Cambridge, MA, 1993), 158-59. 
the matter go [to] the people as it is presented here." He thought it was obvious that the people ought not to be permitted to "decide upon any point they please," because doing so would ensure that it would take another "ten years" to settle the question. The friends of public institutions would "see it upon the hustings all over the state, all mixed up with politics." Similarly, Republican Rufus L. Clarke of Henry County commented on the sharp battle over the insane asylum then being waged among Fairfield, Oskaloosa, Mount Pleasant, and Keokuk. "We all understand perfectly well how local interests operate in such cases; how compromises may spring up, and concessions be made." $\mathrm{He}$ claimed that he did not know, and was unwilling to say, whether there had been any "log-rolling" in the case, although he stated that he had been "approached, and felt upon this subject."

The convention delegates had initially decided to leave the location of the capital city to the legislature. But after additional debate on the placement of various public institutions, the delegates unaccountably changed their minds. Republican William Penn Clarke, the former Whig who had attempted to secure the state university for Iowa City in exchange for removing the capital to Des Moines-and to enshrine both in the new state constitution-was enraged. After further vituperative speeches and more accusations of fraud, the convention once again reversed itself and voted to include in the new constitution the location of both the capital city and the state university (as well as several other public institutions). Some Republicans pondered whether this move would endanger the entire constitution when it was submitted to the popular vote. However, because there was a significant Democratic presence in the convention, and because most Iowans had by now reconciled themselves to the removal of the capital-especially since the new founding document also fairly apportioned other public institutions among contending towns-few really feared such an outcome. Reflecting the commitments of the new Republican Party, the constitution had become somewhat more flexible on the subject of banks, but remained an essentially egalitarian instrument. ${ }^{45}$

44. Debates of the Constitutional Convention, 2:932, 926.

45. Wall, Iowa, 100. 
In the weeks before the new constitution came up for popular vote, three prominent Republicans published a broadside whose purpose was to persuade the people of central Iowa to ratify the new constitution. They focused narrowly on the economic advantages to be gained by relocating the capital. "The entire Des Moines valley," they claimed, would be "materially benefited" by the permanent establishment of the state capital at Des Moines because Polk County had always manifested a willingness to "contribute liberally toward the construction of rail roads. She has already voted a loan of $\$ 300,000$ to the [Mississippi and Missouri Rail Road]. She has pledged herself to the same amount, to the Keokuk and [Fort Des Moines Rail Road] and she is ready to participate largely in the construction of all other roads that will make Des Moines a point on their route. ${ }^{146}$ The ratification of the new state constitution, then, would create prosperity by locating the capital centrally, in an area that had a proven record of supporting transportation improvements.

The 1857 constitution, framed by a 21-15 Republican majority, won the popular vote by a slight margin. The document established the capital at Des Moines, which effectively resolved the removal debate. ${ }^{47}$ But that did not end the disputes. The final battle in Iowa raged over the location of the capitol building itself.

Prominent citizens in Des Moines had already promised funding and town lots in excess of $\$ 100,000$ to locate the capitol on the west side of the Des Moines River. Inexplicably, the commissioners appointed to choose a site for the building decided to locate it on the east side of the river, on a gently rising hill on five acres of ground. That site had been donated by a rival faction of Des Moines businessmen, and was deemed much less valuable. As a result, there was such an uproar in the newspapers that the lower house of the General Assembly established a committee to investigate the matter. The final outcome of the inquiry was somewhat in doubt. Two of the committee members

46. W. H. Farner, J. A. Williamson, and J. C. Savery, Polk County Constitutional Committee, untitled broadside, $7 / 22 / 1857$, State Historical Society of Iowa, Des Moines.

47. Richard, Lord Acton and Patricia Nassif Acton, To Go Free: A Treasury of Iowa's Legal Heritage (Ames, 1995), 90-91. 
found evidence of fraud; the third, upon reflection, decided that the evidence of fraud remained unclear and did not warrant a conviction. In any case, despite the anomalies of the final location, the capitol was built on the east side of the river, and the capital city debate in Iowa ended. ${ }^{48}$

THE BATTLE over the state capital in Iowa revealed an experimentation with the forms of political compromises, alliances, and rhetoric, along with the uses of a creative blend of legislative, constitutional, and private (including, sometimes corrupt) negotiation. This western-style democracy possessed distinct advantages as well as dangers. Perhaps the greatest danger was that this experimentation made for intense geographic rivalries and permitted fraudulent private transactions. On the other hand, the most significant advantage may have been that "local sectionalism" had to give way to fixed ideas about placing the seat of government and courts in a centrally accessible location. This kept alive the commitment to majority rule and to the principle of fair negotiation among political communities. As ideas about democracy and self-government developed in the new states, they often had to make room for the participation of private entrepreneurs, vocal boosters, and shady deals; but they were also fought out on a reasonably level terrain. The capital city struggle in Iowa, as in other midwestern states, reveals how antebellum midwesterners participated in democracy-how they combined their ideals and principles, their personal and local interests, and their patriotism - on the ground.

48. House of Representatives, Seventh General Assembly, Report of the Special Committee Appointed by the House of Representatives, of the Seventh General Assembly, to Investigate Alleged Frauds in the Location of the Capitol (Des Moines, 1858.) 
Copyright of Annals of Iowa is the property of State of Iowa, by \& through the State Historical Society of Iowa and its content may not be copied or emailed to multiple sites or posted to a listserv without the copyright holder's express written permission. However, users may print, download, or email articles for individual use. 